\title{
Lactobacillus sobrius sp. nov., abundant in the intestine of weaning piglets
}

Correspondence

Sergey R. Konstantinov sergey.konstantinov@wur.nl

\author{
Sergey R. Konstantinov, ${ }^{1}$ Elisa Poznanski, ${ }^{2}$ Susana Fuentes, ${ }^{3}$ \\ Antoon D. L. Akkermans, ${ }^{1}$ Hauke Smidt ${ }^{1}$ and Willem M. de Vos ${ }^{1}$
}

${ }^{1}$ Laboratory of Microbiology, Agrotechnology and Food Sciences Group, Wageningen University, Hesselink van Suchtelenweg 4, 6703 CT Wageningen, The Netherlands

${ }^{2}$ Istituto Agrario di S. Michele all'Adige, San Michele all'Adige (TN), Italy

${ }^{3}$ Department of Microbiology, Faculty of Pharmacy, University of Granada, Spain
Lactobacilli are characterized as Gram-positive, non-sporeforming rods and are catalase-negative, non-motile, do not usually reduce nitrate and utilize glucose fermentatively (Hammes et al., 1991). Members of the genus Lactobacillus are not only found on plants and in plant-derived materials, such as silage, grains and foods, but also in the gastrointestinal tract of humans and animals (Vaughan et al., 2002). Recent studies have shown a specific response of a novel and abundant Lactobacillus amylovorus-like phylotype to dietary oligosaccharides in the guts of weaning piglets (Konstantinov et al., 2004). Therefore, culturing and further analysis were needed in order to gain insight into the systematic position of the L. amylovorus-like strains. Here we

Published online ahead of print on 16 September 2005 as DOI 10.1099/ijs.0.63508-0.

Abbreviations: FISH, fluorescence in situ hybridization; FOS, fructooligosaccharides; SBP, sugar beet pulp.

The GenBank/EMBL/DDBJ accession number for the 16S rRNA gene sequence of Lactobacillus sobrius sp. nov. OTU171-001 ${ }^{\top}$ is AY700063.

A figure showing the results of SDS-PAGE analysis and a table detailing the results of DNA-DNA hybridization studies are available as supplementary material in IJSEM Online. report on the isolation of strains related to Lactobacillus amylovorus DSM $20531^{\mathrm{T}}$ from pig intestinal sources and their characterization using a polyphasic approach. The results of this approach indicate that these strains represent a novel species for which the name Lactobacillus sobrius sp. nov. is proposed.

A DNA oligonucleotide probe L-*-OTU171-0088-a-A-18 (5'-CGCTTTCCCAACGTCATT-3') (Konstantinov et al., 2004) targeting the $16 \mathrm{~S}$ rRNA gene of the L. amylovorus-like phylotype OTU171 was used to screen a range of Lactobacillus isolates from piglets (21 days of age) housed at different locations. In total, 192 isolates grown on MRS Lactobacillus-selective agar (Difco) were screened by fluorescence in situ hybridization (FISH) using the CY3-labelled phylotype-specific probe in combination with image analysis as described by Konstantinov et al. (2004). Two $L$. amylovorus-like strains were identified in the faeces of piglets housed on a farm near Wageningen, the Netherlands, and were isolated as strains OTU171-001 ${ }^{\mathrm{T}}$ and OTU171-002. Three strains (OTU171-003, OTU171-004 and OTU171005) were isolated from the faeces of piglets kept on a farm near Bologna, Italy, and one isolate was found in an ileal lumen sample from a piglet reared on a farm near Bristol, 
UK (OTU171-006). These six isolates were selected for further characterization by phenotypic and molecular taxonomic methods. Lactobacillus acidophilus DSM $20079^{\mathrm{T}}$, L. amylovorus DSM $20531^{\mathrm{T}}$, Lactobacillus crispatus DSM $20584^{\mathrm{T}}$, Lactobacillus gallinarum DSM $10532^{\mathrm{T}}$, Lactobacillus helveticus DSM $20075^{\mathrm{T}}$ and Lactobacillus kitasatonis JCM $1039^{\mathrm{T}}$ were used as reference strains.

Cell shape, size and arrangement, Gram-stain and appearance of colonies were determined by using cells grown on MRS agar plates for 2 days at $37^{\circ} \mathrm{C}$. Production of gas from glucose was also examined. The $L$. amylovorus-like isolates hybridizing to the OTU171 probe were Gram-positive, nonspore-forming and non-motile rods and colonies of these strains were white with circular to irregular shapes. Strains were tested for carbohydrate fermentation abilities using the API 50 CHL system (bioMérieux). In addition, the degradation of fructooligosaccharides (FOS) and sugar beet pulp (SBP) by the strains was tested using MRS as basal medium (without carbohydrates) supplied with $1 \%$ FOS or SBP as carbon sources. All strains were found to display similar fermentation characteristics. The phenotypic characteristics that differentiate the L. amylovorus-like strains from the reference strains are summarized in Table 1 . In contrast to L. kitasatonis, all of the novel isolates were able to ferment D-raffinose. The strains grew also in MRS-FOS and MRSSBP media to a final cell density $\left(\mathrm{OD}_{600}\right)$ of 1.81 and $2 \cdot 7$, respectively. The strains produced DL-lactic acid, did not grow at $15^{\circ} \mathrm{C}$, did grow at $45^{\circ} \mathrm{C}$, were catalase-negative and did not produce gas from glucose. DNA G $+C$ content was calculated based on the determination of genomic DNA $T_{\mathrm{m}}$
(Marmur \& Doty, 1962) and the values obtained were estimated to range from 35 to $36 \mathrm{~mol} \%$ (Table 1 ).

$16 \mathrm{~S}$ rRNA gene sequences (approximately $1.5 \mathrm{~kb}$ ) were determined for the six representative strains as described by Konstantinov et al. (2004). Phylogenetic analysis was performed using the ARB software package (Ludwig et al., 2004) (Fig. 1). Sequence similarity calculations performed after a neighbour-joining analysis indicated that the closest relatives of strain OTU171-001 ${ }^{\mathrm{T}}$ were L. kitasatonis (99\%), L. crispatus (98\%), L. amylovorus (97\%) and L. gallinarum $(97 \%)$.

Extraction of whole-cell proteins and their separation by SDS-PAGE were performed using standard protocols (Sambrook et al., 1989). SDS-PAGE protein fingerprints were compared using the BIONUMERICS software package version 3.0 (Applied Maths). When analysed using SDSPAGE, the whole-cell proteins of the six OTU171 strains displayed marked differences from those of the reference strains (see Supplementary Fig. S1 in IJSEM Online). After cluster analysis of the SDS-PAGE protein profiles, the fingerprints of the novel isolates formed a coherent cluster with a similarity greater than $85 \%$; they were related to the type strains examined with a similarity below $70 \%$.

DNA-DNA hybridization experiments were performed with strains OTU171-001 ${ }^{\mathrm{T}}$, OTU171-002 and OTU171-003 and type strains of the nearest Lactobacillus species by filter hybridization according to Klijn et al. (1994) except that $\left[\alpha-{ }^{32} \mathrm{P}\right] \mathrm{dCTP}$ was used for the nick translation and the hybridization temperature was $59^{\circ} \mathrm{C}\left(\sim 25^{\circ} \mathrm{C}\right.$ below $\left.T_{\mathrm{m}}\right)$.

Table 1. Phenotypic characteristics and DNA G+C content of L. amylovorus-like OTU171 strains and closely related lactobacilli

Taxa: 1, L. amylovorus-like OTU171 strains (L. sobrius sp. nov.); 2, L. kitasatonis; 3, L. amylovorus; 4, L. crispatus; 5. L. gallinarum; 6, L. gasseri; 7, L. acidophilus; 8, L. johnsonii; 9, L. helveticus. Data for taxa 2-9, belonging the L. acidophilus group, are from Mukai et al. (2003). +, Positive; D, strain-dependent; D-, usually negative; -, negative; W, weak reaction. All strains produce acid from D-glucose, galactose, D-fructose, D-mannose and maltose and produce DL-lactic acid. No strains produce acid from arabinose, xylose, rhamnose, melezitose or sorbitol.

\begin{tabular}{|c|c|c|c|c|c|c|c|c|c|}
\hline Characteristic & 1 & 2 & 3 & 4 & 5 & 6 & 7 & 8 & 9 \\
\hline DNA G $+\mathrm{C}$ content $(\mathrm{mol} \%)$ & $35-36$ & $37-40$ & $36-38$ & $33-36$ & $36-37$ & $33-34$ & $32-40$ & $33-35$ & $38-40$ \\
\hline Growth at $15^{\circ} \mathrm{C}$ & - & - & - & - & + & - & - & + & - \\
\hline \multicolumn{10}{|l|}{ Fermentation of: } \\
\hline Amygdalin & $\mathrm{D}, \mathrm{W}$ & - & $\mathrm{D}$ & + & + & + & + & + & - \\
\hline Cellobiose & $\mathrm{D}$ & $\mathrm{D}$ & $\mathrm{D}$ & + & + & + & + & + & - \\
\hline Lactose & + & $\mathrm{D}, \mathrm{W}$ & + & + & $\mathrm{D}$ & + & + & + & + \\
\hline Mannitol & $\mathrm{D}, \mathrm{W}$ & $\mathrm{D}, \mathrm{W}$ & - & $\mathrm{D}$ & - & - & - & - & - \\
\hline Melibiose & D & - & $\mathrm{D}$ & + & + & $\mathrm{W}$ & - & D & - \\
\hline D-Raffinose & + & - & D & + & + & - & + & $\mathrm{D}$ & - \\
\hline Ribose & $\mathrm{D}, \mathrm{W}$ & - & - & D & - & - & - & - & - \\
\hline Salicin & $\mathrm{D}, \mathrm{W}$ & $\mathrm{D}$ & + & + & + & + & + & + & - \\
\hline Sucrose & + & + & + & + & + & + & + & + & - \\
\hline Trehalose & $\mathrm{D}$ & $\mathrm{D}^{-}$ & - & $\mathrm{D}$ & - & + & + & D & $\mathrm{D}$ \\
\hline
\end{tabular}




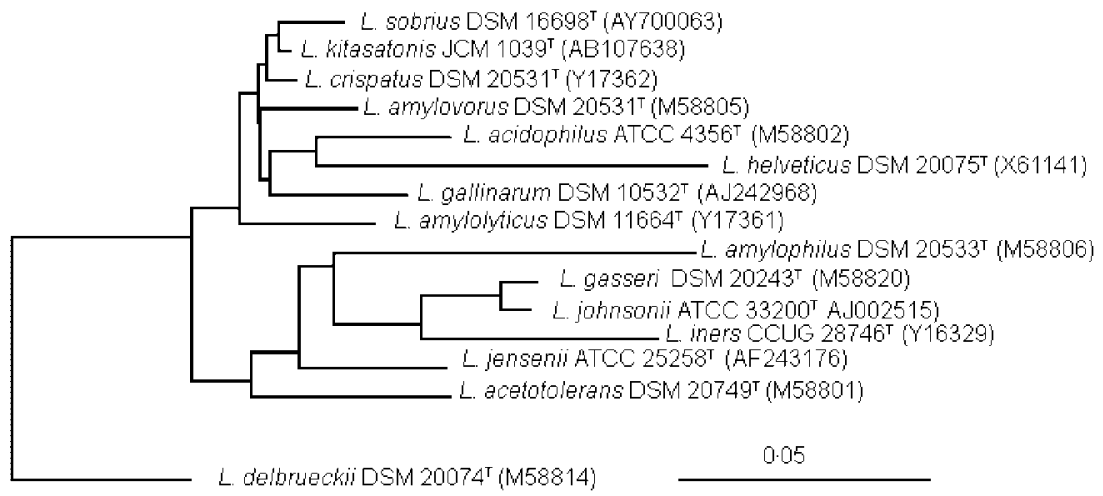

Fig. 1. Phylogenetic analysis of Lactobacillus sobrius OTU171-001 ${ }^{\top}$ and selected members of the L. delbrueckii 16S rRNA gene cluster of the genus Lactobacillus. The tree was calculated using the neighbourjoining method with partial 16S rRNA gene sequences (Escherichia coli positions 1071433) using the ARB software package (Ludwig et al., 2004). Bar, $5 \%$ sequence divergence.

Labelled DNA of strains OTU171-001 ${ }^{\mathrm{T}}$, OTU171-002 and OTU171-003 reassociated at a high level (78-100\%) with unlabelled DNA from the six OTU171 strains, while only low levels of reassociation (2-49\%) were observed with the closely related Lactobacillus species examined (see Supplementary Table S1 in IJSEM Online).

Based on DNA-DNA hybridization values, the ability of the OTU171 strains to ferment D-raffinose and FOS and to grow at $45^{\circ} \mathrm{C}$, it is suggested that the six isolates are members of a single species that is distinct from the closest Lactobacillus species.

To assess the genomic diversity of the six isolates further, PFGE profiles of ApaI-digested chromosomal DNA were generated as described previously (McCartney et al., 1996). The genome size of the isolates was calculated according to the $\lambda$ PFGE standard ladder using the QUANTITY ONE program (Bio-Rad). All isolates displayed distinct PFGE profiles (data not shown) and a mean genome size of $1 \cdot 2 \mathrm{Mb}$ was calculated.

Based on the reported data, we propose the novel species Lactobacillus sobrius with the type strain OTU171-001 ${ }^{\mathrm{T}}$.

\section{Description of Lactobacillus sobrius sp. nov.}

Lactobacillus sobrius (so'bri.us. L. masc. adj. sobrius sober, moderate; in Calvinism, referring to a hard working, invisible person).

Cells are Gram-positive, non-motile, non-spore-forming rods that are $0 \cdot 6-1 \cdot 0 \mu \mathrm{m}$ in width and $2 \cdot 0-20 \cdot 0 \mu \mathrm{m}$ in length and occur singly, in pairs or often in long chains. Colonies are $1 \cdot 4-2 \mathrm{~mm}$ in diameter, circular to slightly irregular to rough in form and white when the organism is grown on MRS agar at $37^{\circ} \mathrm{C}$ for 2 days. There is no growth at $15^{\circ} \mathrm{C}$, but the bacterium grows at $45^{\circ} \mathrm{C}$. The organism is facultatively anaerobic and produces D- and L-lactic acid homofermentatively. Catalase is not produced. Acid is produced without gas formation from D-glucose, D-mannose, maltose, galactose, D-fructose, lactose, aesculin, sucrose, starch, mannitol (two of six strains), cellobiose (three of six strains), salicin (two of six strains), trehalose (two of six strains), amygdalin (two of six strains, weak reaction),
$\mathrm{N}$-acetylglucosamine (two of six strains), ribose (two of six strains, weak reaction), glycogen (three of six strains) and 5-ketogluconate (two of six strains, weak reaction). FOS and unidentified compounds of SBP are also fermented by all strains. There is no acid formation from glycerol, erythritol, D-arabinose, L-arabinose, D-xylose, L-xylose, melezitose, rhamnose, adonitol, methyl $\beta$-xyloside, sorbitol, L-sorbose, dulcitol, inositol, methyl $\alpha$-D-mannoside, methyl $\alpha$-Dglucoside, arbutin, inulin, xylitol, D-turanose, D-lyxose, D-tagatose, D-fucose, L-fucose, D-arabitol, L-arabitol, gluconate or 2-ketogluconate. DNA $\mathrm{G}+\mathrm{C}$ content is 35-36 mol\%.

The type strain, OTU171-001 $1^{\mathrm{T}}\left(=\mathrm{DSM} 16698^{\mathrm{T}}=\mathrm{NCCB}\right.$ $\left.100067^{\mathrm{T}}\right)$, was isolated from pig intestine.

\section{Acknowledgements}

This research was financially supported by the European Communities EC project HEALTHYPIGUT (QLK5-LT2000-00522). E. P. was supported by a grant from the Ministry of Agriculture and Forestry Policy, Italy, within the Program 'Valorizzazione e salvaguardia della microflora autoctona caratteristica delle produzioni casearie italiane'. We are grateful to Wilma Akkermans-van Vliet for excellent assistance with the sequencing analysis. Professor Dr Hans G. Trüper, Department of Microbiology, Universität Bonn, Germany, is specially acknowledged for his help with the etymology of the species name.

\section{References}

Hammes, W. P., Weiss, N. \& Holzapfel, W. (1991). The genera Lactobacillus and Carnobacterium. In The Prokaryotes: a Handbook on the Biology of Bacteria: Ecophysiology, Isolation, Identification, Applications, vol. 2, pp. 1535-1594. Edited by A. Balows, H. G. Trüper, M. Dworkin, W. Harder \& K.-H. Schleifer. New York: Springer.

Klijn, N., Bovie, C., Dommes, J., Hoolwerf, J. D., van der Waals, C. B., Weerkamp, A. H. \& Nieuwenhof, F. F. (1994). Identification of Clostridium tyrobutyricum and related species using sugar fermentation, organic acid fermentation and DNA probes based on specific 16S rRNA sequence. Syst Appl Microbiol 17, 249-256.

Konstantinov, S. R., Awati, A., Smidt, H., Williams, B. A., Akkermans, A. D. L. \& de Vos, W. M. (2004). Specific response of a novel and abundant Lactobacillus amylovorus-like phylotype to dietary prebiotics in the guts of weaning piglets. Appl Environ Microbiol 70, 3821-3830. 
Ludwig, W., Strunk, O., Westram, R. \& 29 other authors (2004). ARB: a software environment for sequence data. Nucleic Acids Res 32, 1363-1371.

Sambrook, J., Fritsch, E. F. \& Maniatis, T. (1989). Molecular Cloning: a Laboratory Manual, 2nd edn. Cold Spring Harbor, NY: Cold Spring Harbor Laboratory.

Marmur, J. \& Doty, P. (1962). Determination of the base composition of deoxyribonucleic acid from its thermal denaturation temperature. J Mol Biol 4, 109-118.
McCartney, A. L., Wenzhi, W. \& Tannock, G. (1996). Molecular analysis of the composition of the bifidobacterial and lactobacillus microflora of humans. Appl Environ Microbiol 62, 4608-4613.

Mukai, T., Arihara, K., Ikeda, A., Nomura, K., Suzuki, F. \& Ohori, H. (2003). Lactobacillus kitasatonis sp. nov., from chicken intestine. Int J Syst Evol Microbiol 53, 2055-2059.

Vaughan, E. E., de Vries, M. C., Zoetendal, E. G., Ben-Amor, K., Akkermans, A. D. \& de Vos, W. M. (2002). The intestinal LABs. Antonie van Leeuwenhoek 82, 341-352. 